\title{
Hydroxyprogesterone Caproate
}

National Cancer Institute

\section{Source}

National Cancer Institute. Hydroxyprogesterone Caproate. NCI Thesaurus. Code C960.

A synthetic progestational agent similar to the endogenous progesterone used in hormone therapy or as a female contraceptive. Mimicking the action of progesterone, hydroxyprogesterone caporate binds to and activates nuclear progesterone receptors in the reproductive system and causes the ligand-receptor complex to be translocated to the nucleus where it binds to and promotes expression of target genes. Due to the negative feedback mechanism seen with progesterone, this agent also blocks luteinizing hormone (LH) release from the pituitary gland, thereby leading to an inhibition of ovulation and an alteration in the cervical mucus and endometrium. Furthermore, without stimulation of $\mathrm{LH}$, estrogen release from the ovaries is stopped, hence impeding the growth of estrogen-sensitive tumor cells. 